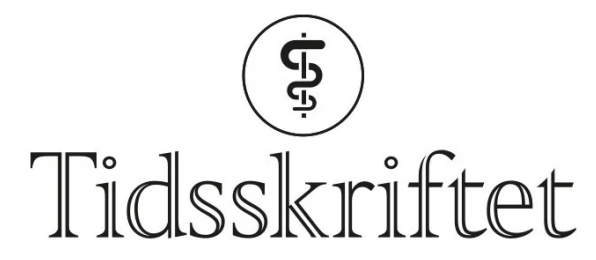

DEN NORSKE LEGEFORENING

\title{
Den store gule oppslagsboken om reisemedisin
}

ANMELDELSER

GUNNAR HASLE

Reiseklinikken

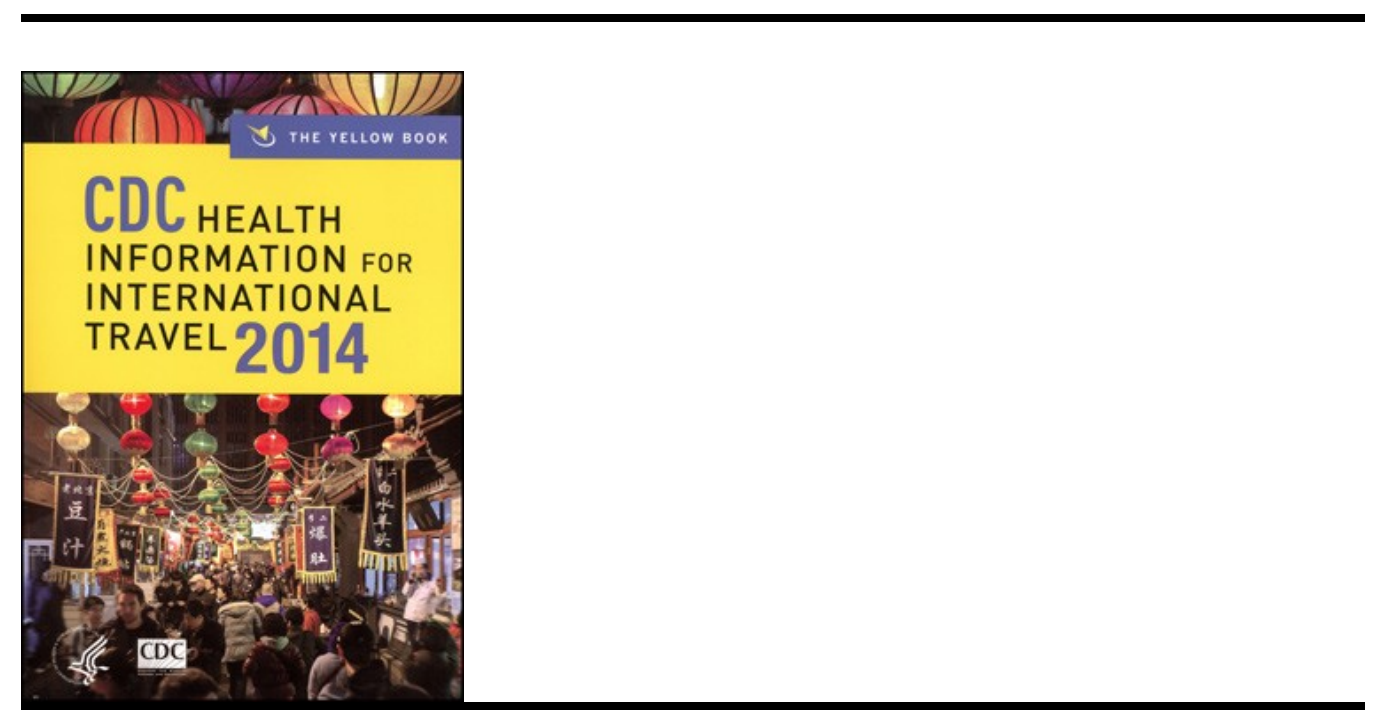

Brunette, Gary W.

CDC health information for international travel 2014

653 s, tab, ill. Oxford: Oxford University Press, 2013. Pris GBP 33

ISBN 978-0-19-994849-9

Det finnes et vell av reisemedisinske lærebøker med overlappende innhold, men det er godt å ha en med autoritet i ryggen når vi gir våre anbefalinger. The yellow book fra Centers for Disease Control and Prevention (CDC) er en slik. Den kommer i ny utgave annethvert år, og sammen med WHOs International travel and health og Folkehelseinstituttets utgivelser gir den basiskunnskap om reisemedisin. Målgruppen er leger, sykepleiere og farmasøyter som gir vaksiner, resepter og råd til folk som skal ut og reise. Den tjener også som oppslagsbok for reiselivsbransjen og organisasjoner med medarbeidere stasjonert utenlands. 
Reisemedisinen omtales i hele sin bredde, herunder konsultasjon før reiser, reisende med spesielle behov, de viktigste infeksjonssykdommene som kan erverves på reise, inkludert oppdaterte utbredelseskart, og utredning av hjemvendte reisende. Det er et svært nyttig kapittel om utvalgte turiststeder, som dekker de fleste reisemålene vi kommer ut for i den reisemedisinske hverdag. Her beskrives aktivitetene de reisende bedriver på de ulike destinasjonene og hvilke risikoer de utsettes for, også de som ikke har med infeksjoner å gjøre.

Dette er en god lærebok i reisemedisin, men ved utredning av infeksjoner hos reisende må den suppleres med lærebøker i infeksjonsmedisin. Gode insidenstall som gir oss grunnlag for å vurdere sykdomsrisikoen for den enkelte reisende er mangelvare, og denne utgivelsen gjør dessverre lite for å avhjelpe dette. Når det gjelder vaksineanbefalinger og malariaprofylakse, er det til dels store forskjeller mellom amerikanske og norske anbefalinger. Mens vi bare unntaksvis anbefaler forebyggende malariamedisiner utenfor Afrika, anbefales her malariamedisin stort sett overalt hvor WHOs verdenskart viser at malaria forekommer. Folkehelseinstituttet og CDC har tilnærmet identiske anbefalinger for barnevaksinene, gulfeber, hepatitt A, japansk encefalitt, meningokokksykdom, tyfoidfeber og rabies, men mens CDC anbefaler de fleste reisende å overveie hepatitt Bvaksine, anbefaler Folkehelseinstituttet vaksinen bare til dem som har ekstra risiko for hepatitt B. Anbefaling om selvmedisinering med antibiotika for alle med turistdiaré er heller ikke i tråd med norske retningslinjer.

The yellow book anbefales til alle som driver med reisemedisin og vaksinasjon. Den må imidlertid suppleres med litteratur basert på norske anbefalinger. Norske reisemedisinere oppfordres til å legge Folkehelseinstituttets anbefalinger til grunn for sin praksis slik at publikum ikke får ulike råd avhengig av hvilket vaksinasjonskontor de henvender seg til.

Hele boken finnes tilgjengelig gratis i nettversjon: www.cdc.gov/travel/yellowbook.

Publisert: 26. november 2013. Tidsskr Nor Legeforen. DOI: 10.4045/tidsskr.13.1152

(C) Tidsskrift for Den norske legeforening 2023. Lastet ned fra tidsskriftet.no 26. april 2023. 